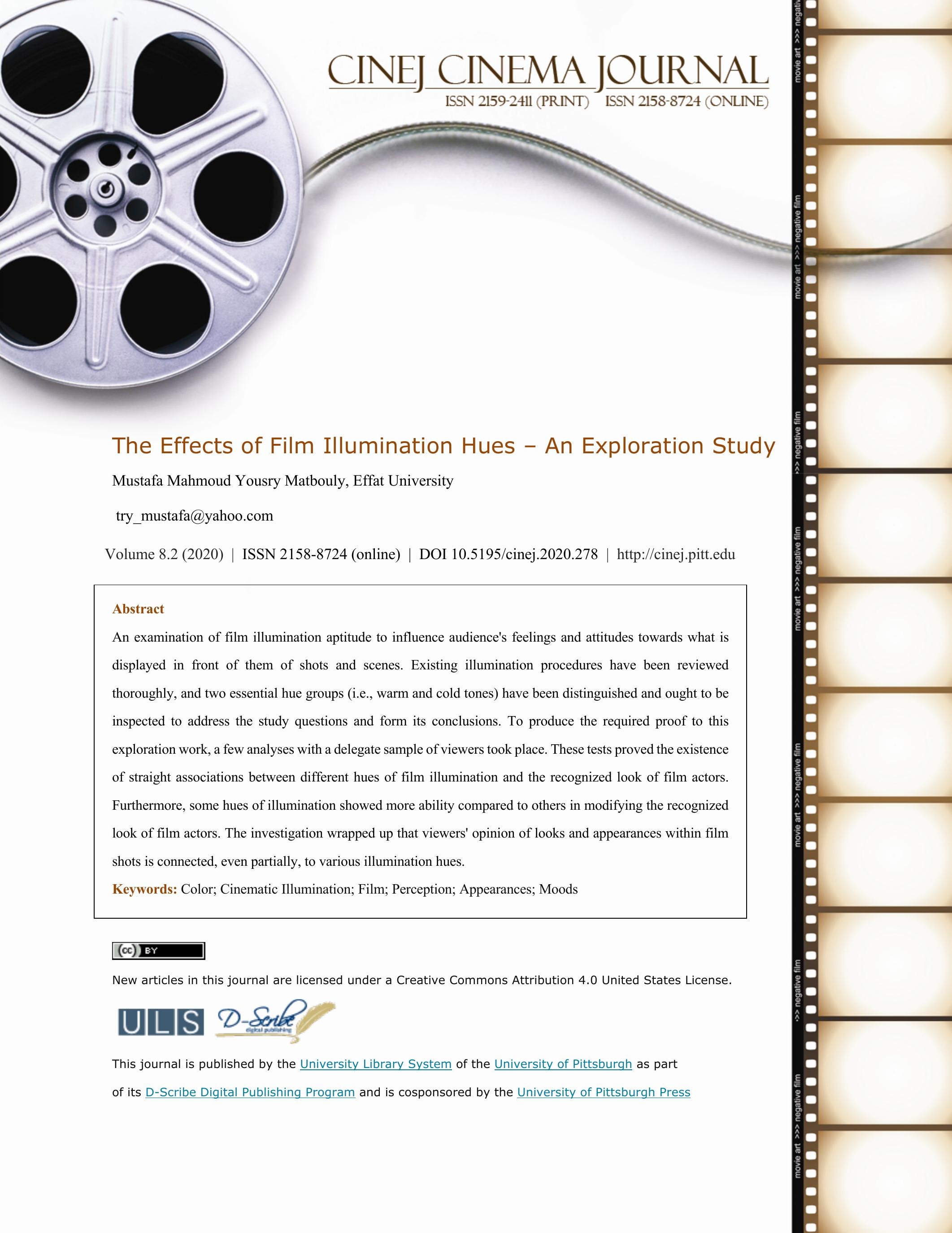




\section{The Effects of Film Illumination Hues - An Exploration Study}

\section{Introduction}

Effective illumination can make a vital contribution to any film; it helps in emphasizing the script ideas and conveying them to the audience. However, cinematic illumination is a design discipline that stands till now with limited academic research in support, and lots of untested tacit rules and tips established through years of practice and experience (Malkiewicz, 2012;

Landau, 2014; Brown, 2018). This study contributes to knowledge by helping in deeply understanding the effects of different hues used in cinematic illumination designs. Each of the two main hue groups of illumination (i.e., warm and cold hues); along with the colorless condition of illumination, will be scientifically associated with certain impressions and feelings inside the viewer. This will be investigated and tested with suitable experimental procedures. Hence, the findings of this study could give cinematographers a clear idea of the moods and appearances the colors they choose for their designs are likely to convey to the audience.

\section{Cinematic illumination:}

Cinematic illumination is well known among cinematographers and film directors for its crucial role in influencing viewers' perception by evoking moods, directing their gaze to important areas, providing visual focus, and conveying visual tension (Lee et al, 2004, and Kaufman, 2004). An illumination design is meant to support the production, to provide an aura, a soul 
perhaps, to the physical body of actor, text and set (Glenn, 2002). Illumination is also a form of visual communication (Kang, 2004); as the cinematographer changes illumination models (i.e. the patterns of direction, quality, and hue in his/her design), s/he alters certain impressions inside the audience:

'The power of light to influence perception and mood is one of the most important aspects of designing with light.' (Van Gorp, 2000: 32)

Seif El-Nasr and Horswill (2004) summarise that the role of illumination is to serve several goals, as follows:

1- Dramatic Goals

- Light all characters in the shot adequately:

- To show the reactions and emotional expressions on a character's face.

- To emphasize the actions and gestures of a character's body.

- Portray visual tension, use colors to create contrast that parallels tension in the scene.

- Guide viewers to the dramatic focus of a scene and provide visual emphasis.

\section{2- Lyrical Goals}

- Provide mood.

3- Aesthetic Goals 
- Establish perception of depth.

- Establish character modelling.

4- Realistic Goals

- Establish logical motivation for the direction of light.

- Establish a sense of visual continuity between frames.

5- Technical Goals

- Provide sufficient illumination for the camera to produce a technically accepted image.

\section{Color of cinematic illumination and its effect:}

There is no question that color can stimulate certain emotions and feelings (Chen, 2011; Serafini,

2013; Bang, 2016; Moyer and Flynn, 2019):

'Perception of color is the single most strongly emotional part of the visual process, it can be utilized to express and reinforce visual information to a great advantage.' (Dondis, 1973: 55)

Studies regarding the difference in effectiveness between both black and white and color images have been explored by several researchers concerning with audio-visual communication media. For example, Scanlon's (1970) experimental study of viewers' perception of color and black and white television images concluded that the use of color changes the emotional impact of images, as well as the presenter's appearance as perceived by audience. Table (1) represents the results of Scanlon's experimental study: 


\begin{tabular}{|l|l|}
\hline Dominating Color & $\begin{array}{l}\text { Image Emotional Impact \& Presenter's Appearance } \\
\text { "As Perceived By Audiences" }\end{array}$ \\
\hline Blue & Respect and authority \\
\hline Yellow & Caution, novelty, and warmth \\
\hline Green & Secure, natural, relaxed or easygoing \\
\hline Red & Human, exciting, hot, passionate, and strong \\
\hline Orange & Powerful, affordable, informal \\
\hline Brown & Informal and relaxed, masculine \\
\hline White & Goodness, purity, delicacy, cleanliness, refinement, and formality \\
\hline Black & Sophistication, power, authority, mystery \\
\hline Silver \& Gold & Regal, wealthy, stately \\
\hline
\end{tabular}

Table 1: Scanlon's (1970) experimental study results.

Furthermore, Berlyne (1974) attempted to piece together knowledge about color with people's responses to art and design; Berlyne concluded that color more than any other aspect of design illustrates meaning, function and form. Russell (1999) adds that perception of color in design depends not only on its physical components (wavelength and intensity) and their psychological association (hue, brightness, and saturation), but also on image/scene size, position, length of presentation, motion, background and surrounding colors.

\section{Audience's response to color:}

Marcella Graham (as cited in Pierman, 1976) shows that human perception of color falls within six broad categories:

\begin{tabular}{|l|l|}
\hline Physiological & $\begin{array}{l}\text { Changes in blood pressure, pulse rate, automatic nervous system, } \\
\text { hormonal activity, rate of tissue oxidation and growth. }\end{array}$ \\
\hline
\end{tabular}




\begin{tabular}{|l|l|}
\hline Within the Eye & $\begin{array}{l}\text { Change in size of pupil, shape of lens, position of eyeball, chemical } \\
\text { response of retinal nerve endings. }\end{array}$ \\
\hline Cognitive & $\begin{array}{l}\text { Memory and recall illusion and perceptive confusion, values } \\
\text { judgement, associative response. }\end{array}$ \\
\hline Mood & Stimulating, irritating, cheerful, relaxing, boring, exciting, melancholy. \\
\hline Impressionistic & $\begin{array}{l}\text { Space seems larger, smaller, warmer, cooler, clean or dirty, bright or } \\
\text { drab; people appear healthy or unhealthy, food is appetizing or not, } \\
\text { older, younger, old, new. }\end{array}$ \\
\hline Associative & $\begin{array}{l}\text { With nature, with technology, religious and cultural traditions, with art } \\
\text { and science, typical or atypical. }\end{array}$ \\
\hline
\end{tabular}

Table 2: Marcella Graham's six categories of human color perception.

Additional clarification could be identified from the more recent work of Henry et al (2000),

Park and Guerin (2002), Rotem (2003), and Holtzschue (2017); those researchers confirmed that human's color processing takes five different forms: Biological response is outside of our control. It remains outside the scope of how we as individuals think or feel about a certain hue, and it includes cellular response. Collective unconscious is a reservoir of primordial images. This reservoir extends back through generations and, therefore, is not based upon individuals' experiences. For example, in most parts of Europe, black is for mourning, while in China, and some other parts of East Asia, white is the color of mourning. Also, in most of Europe, white is the color of purity, worn by the bride at her wedding; though in northern parts of Portugal brides wear black for their wedding day. 
Conscious symbolism: colors also have symbolic meanings; i.e. learned responses... For example, red is symbolic for both fire and passion. Blue, on the other hand, is associated both with royalty (e.g. the color "royal blue") and depression (e.g. feeling "blue").

Cultural influences: ethnicity, geographic location and local mannerisms affect the way people process color. It has been shown that people from strongly sunlit countries tend to prefer warm, bright colors, while those from countries with less sunlight tend to prefer cooler, less intensity saturated colors.

1) Personal relationships: our individual likes and dislikes of colors are based on our own color memories.

\section{Warm and cold hues and audience's reaction:}

The psychological impact of colors is mainly based on the use of ranges of cold and warm hues

(Castellanos et al, 1994). Kingdom (2003) suggests that most people, when faced with visual presentations, prefer illumination which tends towards warmth. Further psychological experiments indicate that most people are more accepting of 'warm' hues of light at low brightness levels, while they accept 'cooler' hues at higher levels of illumination:

'We expect illumination to be of a high color temperature when luminance levels are high because we refer them unconsciously to daylight, which has a relatively high color temperature. While, we expect low color temperatures when luminance levels 
are low - perhaps by association with firelight, candlelight, and so forth.' (Lam, 1992: 51)

In fact, associating the colors of fire - reds, yellows, and oranges - with warmth is not just an abstract notion, as physiological research indicates that under red illumination our bodies secrete more adrenalin, increase blood pressure and rate of breathing, and raise our temperature slightly. On the other hand, we associate blues and greens with the cooling qualities of water and trees, and physiological research again shows that green or blue lights slow our heartbeat, decrease our temperature, and relax our muscles (Bloomer, 1990; Hornung, 2012; Schwartz, 2017).

\section{Research methods and general procedures:}

Research in emotions and concepts perception from visual material often uses a simple stimulusresponse approach to study the immediate emotional responses from these media. Data are captured through the use of a multiple-choice form, which can be analysed via quantitative analysis methods (Ericsson and Simon, 1993). The design of this study followed the same approach.

This study hypothesises that different colors of cinematic illumination could alter audience's impressions about the mood and appearance of film characters and the whole image. Hence, the 
impact of the two basic color groups of illumination (i.e., warm, and cold hues) was measured in a series of repeated-measures experiments conducted with a representative sample of viewers:

'Measuring the ability and effectiveness of an image to communicate the intent of its creator can only be conducted whereby participants perform specific tasks on sets of visual stimuli.' (Gooch et al, 2004: 28)

That involved the production of a number of cinematic images (Appendix A); each image was produced under a specific illumination design with a different color. Each audience during the experimental sessions watched the produced images and choose from the provided form the adjective(s) best describing his/her impression towards every image. Further, and since, many factors, beside the color of illumination, could affect audience's impressions towards the appearance and mood of film characters, hence, this study attempted to control the effect of all those non-illumination factors during the experiments to focus only on measuring the role of color. With all other non-illumination elements of the production kept constant and exactly the same in all the produced images, the changes in viewers' opinions from image to another should therefore be related to the color used.

Moreover, and in order to construct a valid and reliable measure of the moods and appearances that different hues of illumination design could give to film characters and convey to the audience, a robust set of mood adjectives was identified. The adjectives were obtained 
from adjective-based measures of mood used in psychological studies (Grawitch, 2004; Boyle, 1987; Vanstone, 1998), along with the "Profile of Mood States" (Mc Nair et al, 1971), which is reported by many researchers as an effective measuring instrument in detecting changes in mood following experimental procedures intended to affect mood... Finally, the following set of mood adjectives was produced:

- Please indicate one choice for each image displayed on the screen in front of you:

Image \#

In this image the character appears:

$\begin{array}{ll}\square \text { Happy } & \square \text { Angry } \\ \square \text { Relaxed } & \square \text { Mysterious } \\ \square \text { Energetic } & \square \text { Depressed } \\ \square \text { Alert } & \square \text { Sad } \\ \square \text { Tense } & \square \text { No Mood } \\ \square \text { Others, please specify: .................. }\end{array}$

Table 3: The set of appearance and mood adjectives examined during the study (as it was presented to participants in the experiments form).

Results \& Discussion: 
The viewers' sample employed in this study consisted of 31 participants, 13 of them were male and 18 were female. All participants were college students who come from different backgrounds, with ages range between 18 to 21 years old.

\section{White/Colorless light:}

$23.41 \%$ of the participants said that the character they watched during the experiments under different conditions of colorless/white illumination had no mood at all, in other words, the character's appearance was mainly neutral (Chart 1).

\begin{tabular}{|c|c|c|c|c|c|c|c|c|c|c|}
\hline \multicolumn{11}{|c|}{ White/Colorless Light } \\
\hline $\begin{array}{l}\text { Adjectiv } \\
\text { e }\end{array}$ & Happy & $\begin{array}{l}\text { Relax } \\
\text { ed }\end{array}$ & $\begin{array}{l}\text { Energ } \\
\text { etic }\end{array}$ & $\begin{array}{l}\text { Ale } \\
\mathrm{rt}\end{array}$ & $\begin{array}{l}\text { Ten } \\
\text { se }\end{array}$ & $\begin{array}{l}\text { Ang } \\
\text { ry }\end{array}$ & $\begin{array}{l}\text { Mysteri } \\
\text { ous }\end{array}$ & $\begin{array}{l}\text { Depress } \\
\text { ed }\end{array}$ & Sad & $\begin{array}{l}\text { No } \\
\text { Mood }\end{array}$ \\
\hline $\begin{array}{l}\text { Viewers' } \\
\text { Opinion } \\
\text { s }\end{array}$ & $\stackrel{\stackrel{0}{m}}{\stackrel{m}{\forall}}$ & $\begin{array}{l}\stackrel{0}{i n} \\
n \\
\pm\end{array}$ & $\begin{array}{l}\stackrel{0}{0} \\
\stackrel{0}{0} \\
\infty\end{array}$ & $\begin{array}{l}\stackrel{0}{0} \\
\stackrel{0}{0} \\
\stackrel{0}{0}\end{array}$ & $\begin{array}{l}\stackrel{0}{i} \\
\stackrel{1}{=}\end{array}$ & 犬े & $\begin{array}{l}\stackrel{0}{\infty} \\
n \\
\\
\end{array}$ & ஓ̊ & $\dot{0}_{0}^{\circ}$ & 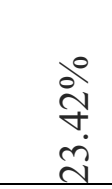 \\
\hline
\end{tabular}

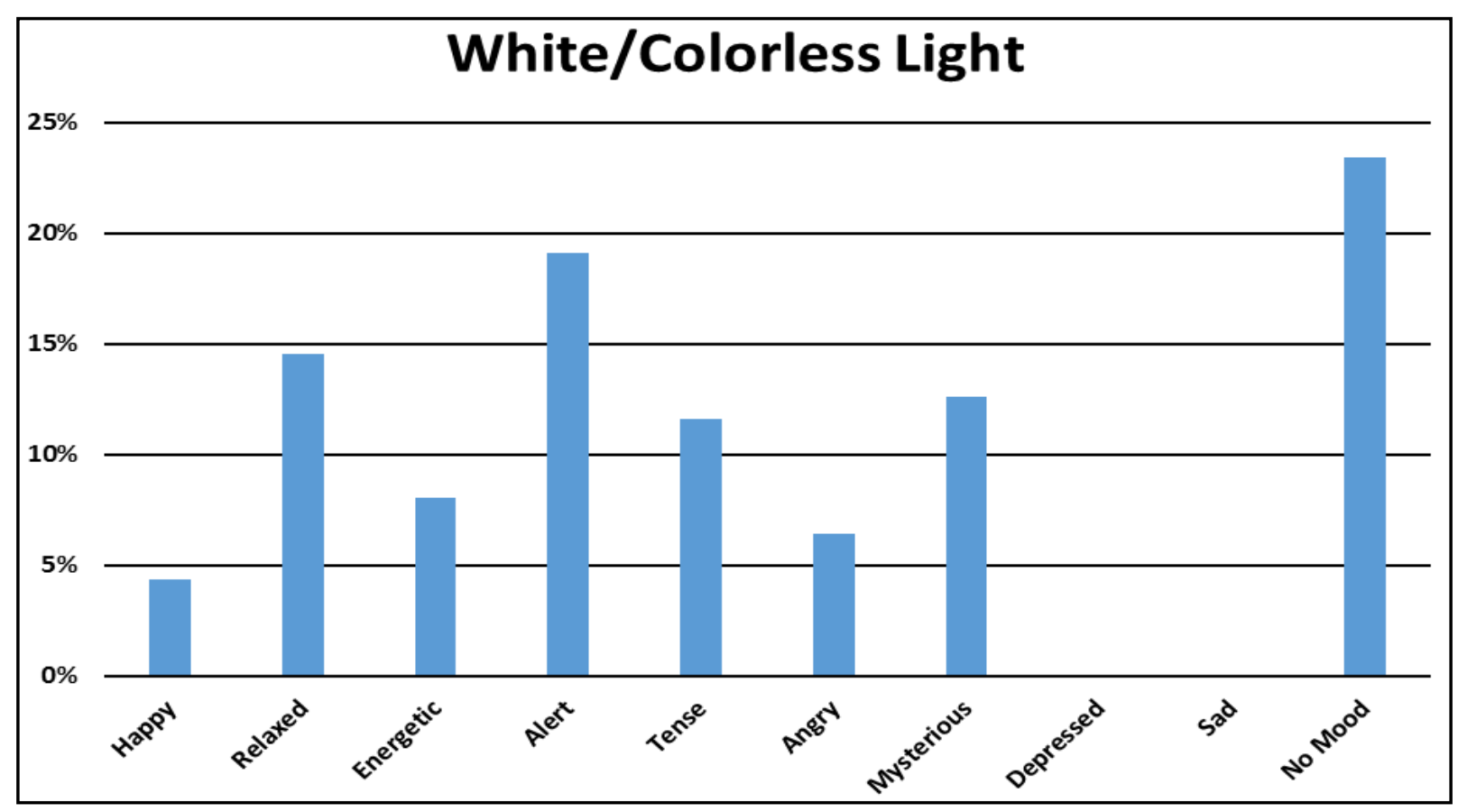

Chart 1: Viewers' opinions regarding the moods and appearances reinforced by white/colorless light.

White/Colorless Illumination Condition: 


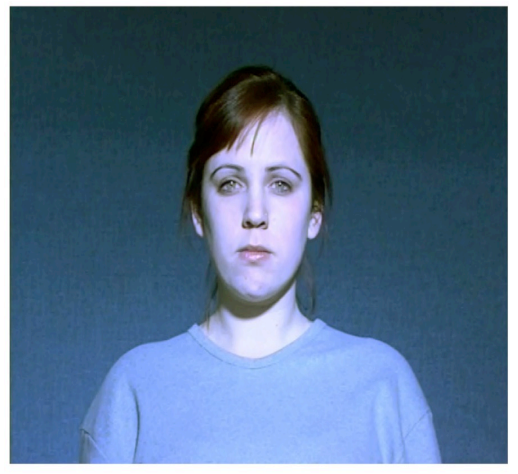

Frontal White Light

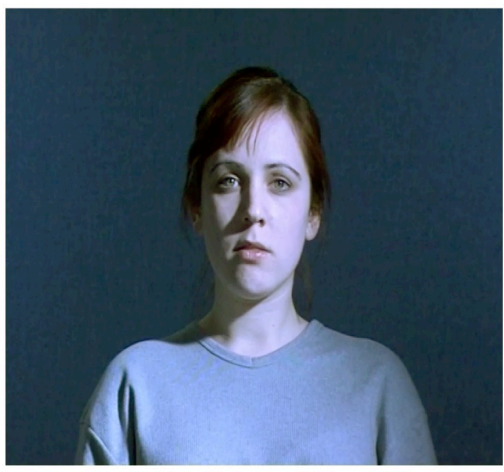

Cross White Light

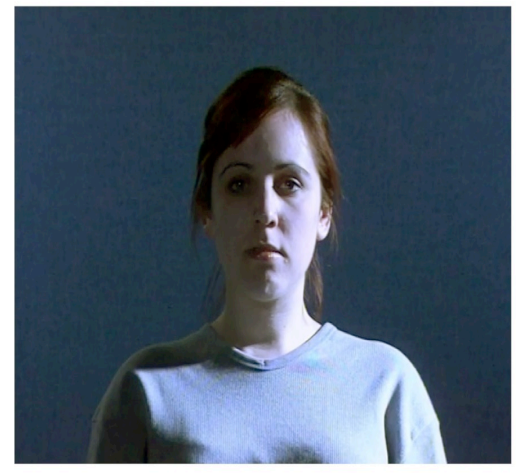

Side White Light

The relaxed appearance came third within viewers' choices by $14.55 \%$ of all the responses,

and after the alert adjective. Alert was the second most chosen adjective by the viewers to

describe the appearance and mood of the character under various conditions of white

illumination... In brief, white/colorless illumination may not create a specific mood or appearance on film characters. However, this could be changed to an alert or a relaxed appearance depending on the direction (e.g. frontal, cross, or side) and/or the quality of the illumination (i.e. its hardness or softness).

The viewers' qualitative answers coped fully with their quantitative determination of the "no mood" appearance to be the probable effect of white light on what it illuminates of characters: 'Emotionless. 'Very difficult to describe. 'No particular mood. 'Neutral, face difficult to read.' 'Fairly natural.' 


\section{Warm light:}

$25.01 \%$ of the viewers pointed out that warm illumination helped in making the character look alert. While, $18.88 \%$ of them suggested that warm light could cause the character to appear in a tense mood (Chart 2).

\begin{tabular}{|c|c|c|c|c|c|c|c|c|c|c|}
\hline \multicolumn{11}{|c|}{ Warm Light } \\
\hline $\begin{array}{l}\text { Adjectiv } \\
\text { e }\end{array}$ & Happy & $\begin{array}{l}\text { Relax } \\
\text { ed }\end{array}$ & $\begin{array}{l}\text { Energe } \\
\text { tic }\end{array}$ & $\begin{array}{l}\text { Ale } \\
\mathrm{rt}\end{array}$ & $\begin{array}{l}\text { Ten } \\
\text { se }\end{array}$ & $\begin{array}{l}\text { Angr } \\
\mathrm{y}\end{array}$ & $\begin{array}{l}\text { Mysteri } \\
\text { ous }\end{array}$ & $\begin{array}{l}\text { Depress } \\
\text { ed }\end{array}$ & $\mathrm{Sad}$ & $\begin{array}{l}\text { No } \\
\text { Mood }\end{array}$ \\
\hline $\begin{array}{l}\text { Viewers' } \\
\text { Opinion } \\
\text { s }\end{array}$ & $\frac{\partial}{a}$ & $\begin{array}{l}\stackrel{0}{0} \\
\infty \\
\infty \\
\infty\end{array}$ & $\begin{array}{l}\infty_{0}^{\circ} \\
0 \\
0 \\
0\end{array}$ & $\begin{array}{l}a^{0} \\
0 \\
a \\
a\end{array}$ & $\begin{array}{l}\circ \\
\infty \\
\infty \\
\infty \\
\end{array}$ & $\begin{array}{l}\stackrel{0}{0} \\
\stackrel{0}{+} \\
\dot{+}\end{array}$ & $\begin{array}{l}\stackrel{0}{i n} \\
\stackrel{5}{i} \\
\stackrel{1}{1}\end{array}$ & $\begin{array}{l}\stackrel{0}{0}^{\circ} \\
\infty \\
i\end{array}$ & $\begin{array}{l}\stackrel{0}{0} \\
\infty \\
i\end{array}$ & ᄋ̊ \\
\hline
\end{tabular}

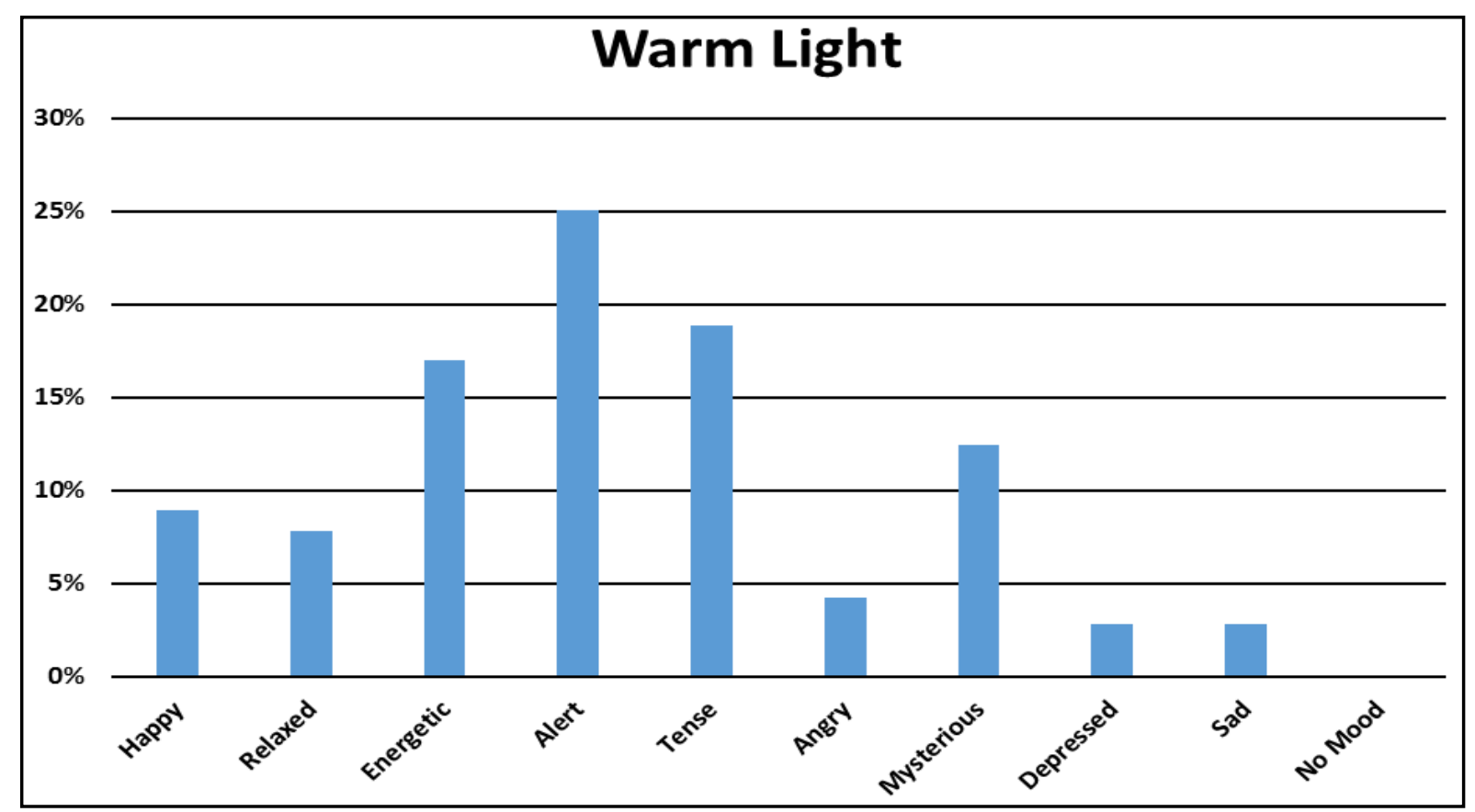

Chart 2: Viewers' opinions regarding the moods and appearances reinforced by warm light.

In regard to the ability of warm illumination to participate in making film characters appear in an angry mood: the viewers did not choose angry as one of the primary moods or appearances associated with film characters when illuminated with a warm light. This finding could be considered as one of the important of this study, as it is widely believed among cinematographers 
that using warm color illumination in illuminating cinematic scenes helps in giving an angry

mood to the characters.

\section{Warm Illumination Condition}

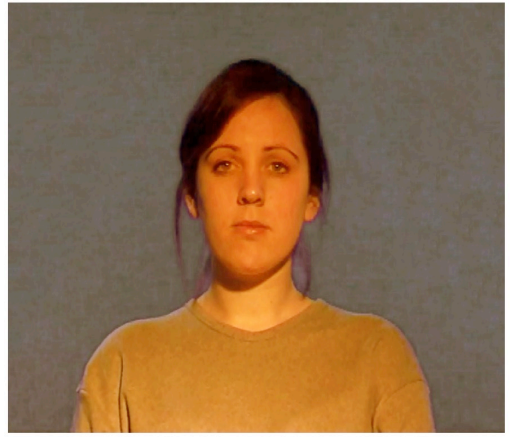

Frontal Warm Light

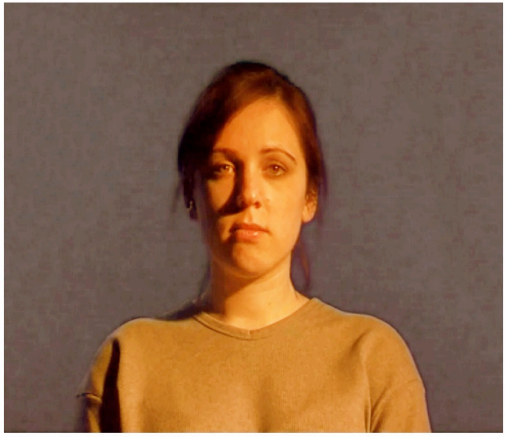

Cross Warm Light

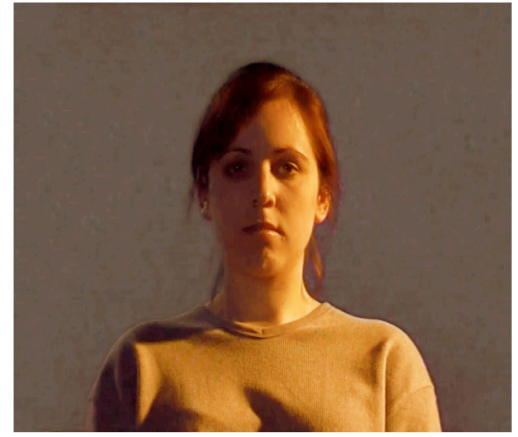

Side Warm Light

The viewers showed to somehow similar opinions to the above quantitative ones when they

described in words their attitudes towards the effect of warm illumination on the character:

'Warm.'

'Warm tones from light source... warm skin tones and background.', 'Alive and friendly.',

'Positive.', 'Healthy.', 'Comfortable.'

According to the viewers' qualitative opinions mentioned above, "warm" could be added to the statistical results of the appearances and moods that warm illumination may reinforce on film characters. However, determining a specific robust definition of the term 'warm' is not quite easy and could drive us towards contradictory directions. Some people, for example, see warm as 
an indication of being happy, friendly and alive, while others may use the same term to describe an angry or a nervous person.

\section{Cold light:}

Tense was the viewers' most chosen mood adjective to describe their impression towards the

effect of cold illumination on the character. While, $18.46 \%$ of them suggested that cold

illumination has the ability to add a sad mood to the cinematic scenes it illuminates. Moreover,

$16.3 \%$ of the viewers said that cold illumination made the character appear mysterious (Chart 3 ).

\begin{tabular}{|c|c|c|c|c|c|c|c|c|c|c|}
\hline \multicolumn{11}{|c|}{ Cold Light } \\
\hline $\begin{array}{l}\text { Adjectiv } \\
\text { e }\end{array}$ & Happy & $\begin{array}{l}\text { Relax } \\
\text { ed }\end{array}$ & $\begin{array}{l}\text { Energ } \\
\text { etic }\end{array}$ & $\begin{array}{l}\text { Ale } \\
\mathrm{rt}\end{array}$ & $\begin{array}{l}\text { Ten } \\
\text { se }\end{array}$ & $\begin{array}{l}\text { Ang } \\
\text { ry }\end{array}$ & $\begin{array}{l}\text { Mysteri } \\
\text { ous }\end{array}$ & $\begin{array}{l}\text { Depress } \\
\text { ed }\end{array}$ & $\mathrm{Sad}$ & $\begin{array}{l}\text { No } \\
\text { Mood }\end{array}$ \\
\hline $\begin{array}{l}\text { Viewers' } \\
\text { Opinion } \\
\text { s }\end{array}$ & $\frac{a}{a}$ & $\begin{array}{l}\text { 点 } \\
\text { in } \\
\text { in }\end{array}$ & $\frac{\partial^{\circ}}{i}$ & ì & $\begin{array}{l}{ }_{0}^{0} \\
\infty \\
\infty \\
\infty\end{array}$ & $\frac{\partial^{0}}{n}$ & ก̊? & $\begin{array}{l}00 \\
\dot{0} \\
\infty \\
i\end{array}$ & $\begin{array}{l}0 \\
\dot{0} \\
\dot{0} \\
\dot{0}\end{array}$ & ठํ \\
\hline
\end{tabular}

\section{Cold Illumination Condition}

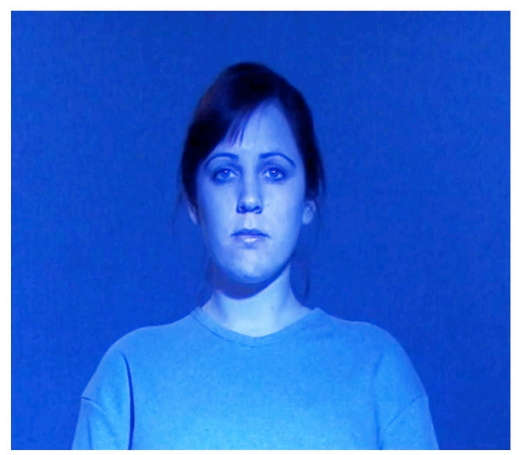

Frontal Cold Light

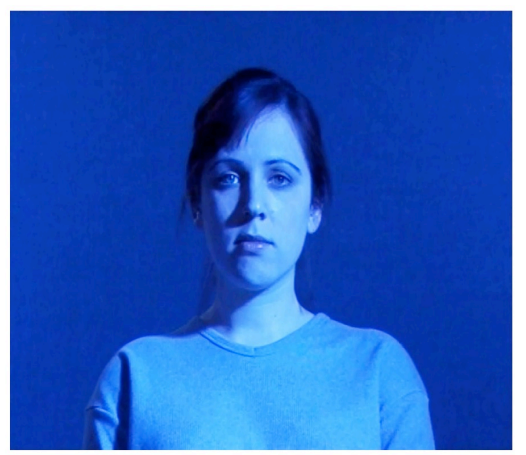

Cross Cold Light

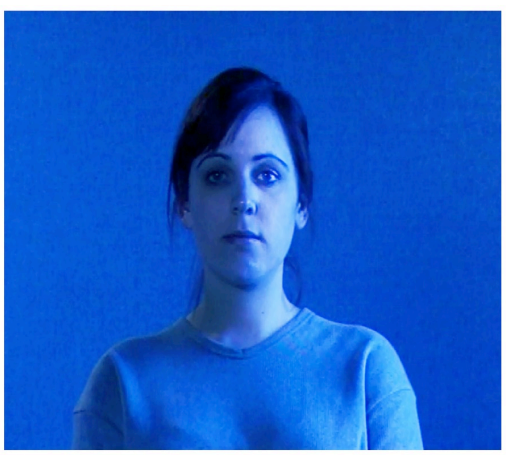

Side Cold Light 


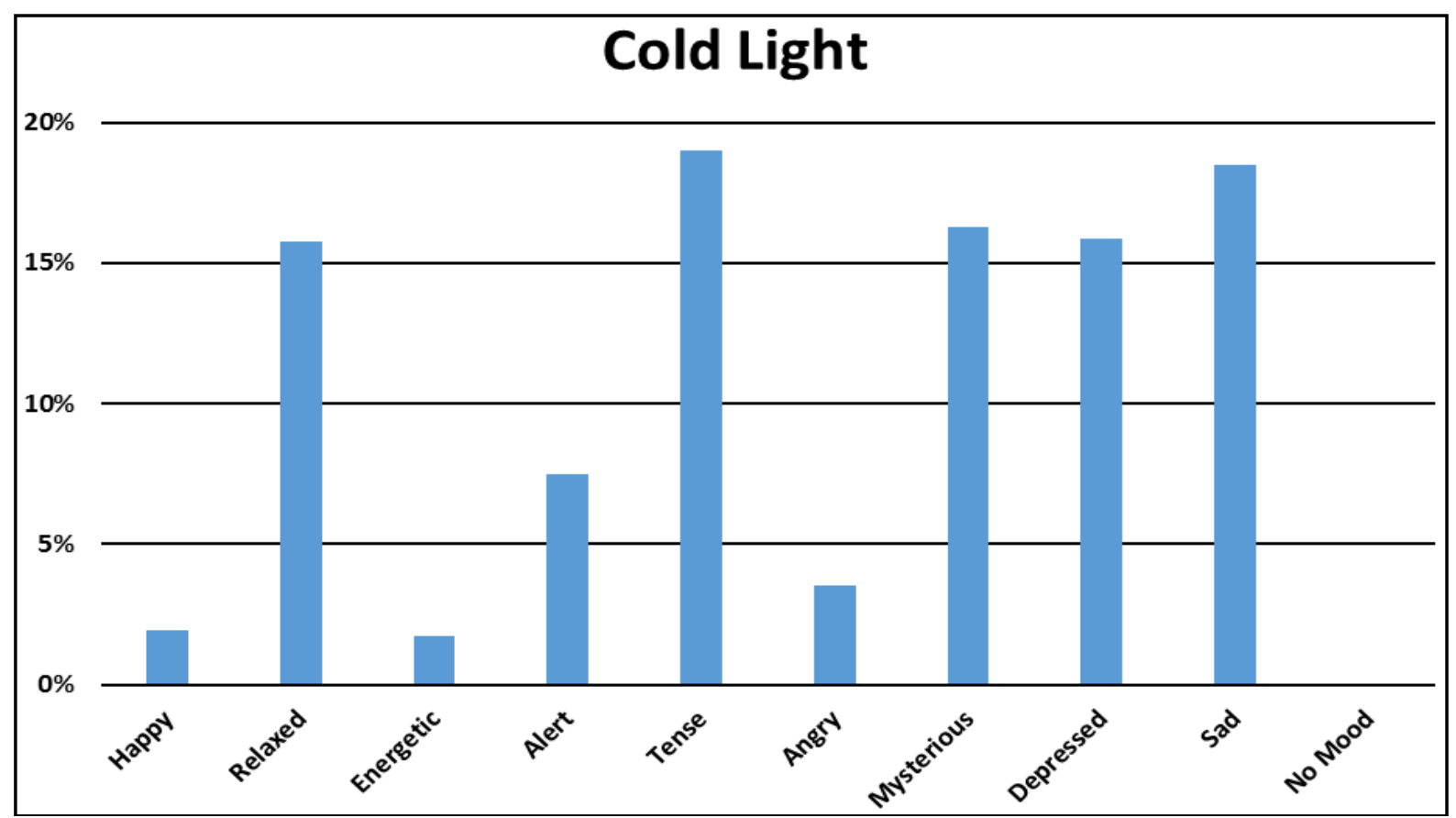

Chart 3: Viewers' opinions regarding the moods and appearances reinforced by cold light.

Meanwhile, and as presented within Chart 3, 15.75\% of the viewers confirmed that cold illumination gave them the impression that the character looks relaxed. The depressed mood gained also a considerable percent of the viewers' choices.

"Cold" was the term mentioned mostly by the viewers within their individual qualitative opinions on the moods strengthened by cold light. Beside cold, the viewers noted some other words to declare their feeling about cold illumination, the following are examples:

'Night-like lighting.', 'Moony.', 'Suggests a melancholy appearance.', 'Dreamy.', 'Morning light.', 'Gloomy.' 


\section{Summary of main findings:}

I. In its ability to influence audience's impression and attitude towards the cinematic image, the color element of cinematic illumination design could exceed other elements of illumination (e.g. illumination direction and quality). The theory of color superiority over other visual elements is well established within other disciplines such as fine art, and graphic design; the present study showed the accuracy of this theory in the context of cinematic illumination design.

II. Cold hues of cinematic illumination (e.g., blue, green, etc.) are relatively more effective and have higher influencing on viewers' attitudes than warm hues (e.g., orange, red, etc.).

III. Colorless/white illumination is mainly neutral; it does not help in creating a specific mood in cinematic images. However, with different directions and/or qualities of illumination, white illumination may have an effect on the perceived appearance and mood of film characters.

IV. Warm illumination (e.g., orange, red, etc.) could help in giving an alert/energetic mood to the cinematic scenes it illuminates.

V. Warm illumination cannot reinforce an angry appearance/mood on characters' faces it illuminates.

VI. Depending on both its quality and direction, cold illumination (e.g., blue, green, etc.) could promote a tense and/or a sad appearance on characters' faces besides a hint of mystery. 


\section{Conclusion:}

Perhaps the greatest knowledge gained from this study was the understanding that the variable of color within the composition of cinematic illumination design is more complex than might be anticipated. The critical evaluation of existing cinematic illumination techniques revealed that there is a lack of knowledge about how different colors of illumination could influence viewers' attitudes and impressions towards what they watch of images. Guided by suitable methods of enquiry, this study has helped in understanding the possible effects of the two basic groups of illumination colors (i.e., warm, and cold hues) on cinematic images. The study demonstrated the ability of cinematic illumination design to help in conveying different emotions and moods to the audience. It showed the effects of changing the color of illumination on the appearance and mood of film characters and the whole image. Research evidence suggested that some hues of illumination are more effective and meaningful than others. If we are to provide the audience with more effective and meaningful images, efforts should be made to design illumination that is able to play a more active role in conveying film ideas and concepts... As such, the following

\section{guidelines are proposed:}

Creating the mood in the cinematic image with only the illumination element is neither easy nor required in real life situations. Illumination design is best suited to reinforce the mood created by 
other compositional elements of the image. Although this study found that illumination may

create the mood independently, that mood will not be as significant or strong as it would be if other image elements helped in creating it in addition to illumination.

Cinematographers should be aware that the hue of illumination is most of the time more effective than other illumination elements.

To help in giving film characters a happy mood and the whole scene a delightful sense, using of warm illumination is recommended.

The warm hue of illumination should be considered if film characters are to appear in an energetic mood to the viewers.

If the intention is to reinforce a sense of alertness within the cinematic image, cinematographers are recommended to apply warm hues of illumination.

Cinematographers should depend on using cold hues of illumination in order to promote a tense mood in the cinematic image.

The cold hue of illumination should be used to reinforce a mysterious mood on characters' faces and the whole cinematic image.

The cold hue of illumination is also the factor that can help in adding a sense of depression or a sad look to the faces of film characters. 
The findings of this study should act as guidance for cinematographers in developing their illumination designs and in selecting suitable approaches to deliver film ideas to the audience.

\section{Further research:}

This study should be considered as a starting point that can be explored further; i.e. many

research directions could be envisioned as a follow-up to this study. One type of this follow-up research would be studies filling in the part of the framework the present study did not examine.

The current study has tested different colors of illumination design used only with film characters; location and set illumination design along with special effects techniques of illumination are possible subjects for further research. The current set of stimuli was also restricted to only two of the endless color hues that could be utilised in cinematic illumination design. This exclusion of stimuli in other colors of illumination opens the door to further investigation to fill in the missing portion of the framework.

\section{REFERENCES}

Akser, M. (2011). Reinvigorating film studies: an immodest proposal. CINEJ Cinema Journal, $1(1), 1-3$.

Bang, M. (2016). Picture This: How Pictures Work. Chronicle Books LLC. Revised edition. 
Berlyne, D. E. (ed.) (1974). Studies in the New Experimental Aesthetics. Washington, DC: Hemisphere.

Bloomer, C. M. (1990). Principles of visual perception. New York; Van Nostrand Reinhold Company.

Boyle, G. J. (1987). A cross-validation of the factor structure of the Profile of Mood States: Were the factors correctly identified in the first instance?. Psychological Reports, 60(2), 343-354.

Brown, B. (2018). Motion Picture and Video Lighting 3rd Edition. London: Routledge.

Castellanos, J., Delicado, J., Dominguez, C., \& Rigo, C. (1994, October). Hypermedia method to teach concepts of colour through art. In Proceedings of the second ACM international conference on Multimedia (pp. 321-327).

Chen M. (2011). Visual Literacy for Theatre. Linus Publications.

Dondis, D. A. (1973). A primer of visual literacy. Cambridge: MIT Press.

Ericsson, K. A., and Simon, H. A. (1993). Protocol analysis: Verbal reports as data. Cambridge: MIT Press.

Glenn, B. L. (2002). 'The Three Penny Opera: Designing lights with brecht'. Mphil thesis. Louisiana State University.

Gooch, B., Reinhard, E., \& Gooch, A. (2004). Human facial illustrations: Creation and psychophysical evaluation. ACM Transactions on Graphics (TOG), 23(1), 27-44.

Grawitch, M. J. (2004): 'Comparing the structural and functional approaches to mood: Design and validation of the approach-avoidance mood measure'. Ph.D. thesis. Saint Louis University.

Henry, R. C., Mahadev, S., Urquijo, S., \& Chitwood, D. (2000). Color perception through atmospheric haze. JOSA $A, 17(5), 831-835$.

Holtzschue, L. (2017). Understanding Color: An Introduction for Designers. 5th Edition. Wiley 
Hornung, D. (2012). Color: A workshop for artists and designers (A practical guide on color application for artists and designers). 2nd Edition. Laurence King Publishing

Kang, J. (2004). The effect of light on the movement of people. PhD thesis. University of Minnesota.

Kaufman, D. (2004). Light conversation. Back Stage. 45(17): 45-48.

Kingdom, F. A. (2003). Color brings relief to human vision. Nature Neuroscience. 6(6): 641644.

Lam, W. M. (1992). Perception and lighting as form-givers for architecture. New York: Van Nostrand Reinhold.

Landau, D. (2014). Lighting for Cinematography: A Practical Guide to the Art and Craft of Lighting for the Moving Image (The CineTech Guides to the Film Crafts). Bloomsbury Academic.

Lee, H. C., Hao, X., and Varshney, A. (2004). Light collages: Lighting design for effective visualization. IEEE Visualization 2004. October 10 - 15. Austin, Texas, USA. p.p. 281 -288.

Malkiewicz, K. (2012). Film Lighting: Talks with Hollywood's Cinematographers and Gaffers. Revised Edition. Touchstone.

Mc Nair, D. M., Lorr, M., and Droppleman, L. F. (1971). Profile of Mood States: Manual. San Diego: CA: Educational and Industrial Testing Service.

Misek, R. (2010). Chromatic cinema: a history of screen color. Wiley-Blackwell.

Moyer, D. and Flynn, B. (2019). Visual Literacy Workbook: For Graphic Design and Fine Art Students. Oxford University Press.

Park, Y. and Guerin, D. (2002). Meaning and preference of interior color palettes among four cultures. Journal of Interior Design. 28(1): 27 - 39. 
Pierman, B. C. (ed.) (1976). Color in the health care environment. Proceedings of a special workshop held at the National Bureau of Standards, Gaithersburg, Maryland. November 16, 1976. Washington: Department of Commerce.

Rotem, O. (2003). The world as one whole: The syntactic role of color in film. KINEMA. Spring 2003.

Russell, P. M. (1999). Focused instructional multimedia design guidelines. Volume one. PhD thesis. Staffordshire University.

Scanlon, T. J. (1970). Viewer Perceptions on Color, Black and White TV: An Experiment. Journalism Quarterly, 47(2), 366-368.

Schwartz, S. (2017). Visual Perception: A Clinical Orientation, 5th Edition. McGraw-Hill Education.

Serafini, F. (2013). Reading the Visual: An Introduction to Teaching Multimodal Literacy. Teachers College Press.

Seif El-Nasr, M. and Horswill, I. (2004). 'Automating lighting design for interactive entertainment'. ACM Computer in Entertainment. 2(2): Article 05.

Street, S., \& Yumibe, J. (2019). Chromatic modernity: Color, cinema, and media of the 1920s. New York: Columbia University Press.

Tomasulo, F. (2019). Teaching creativity: a practical guide for training filmmakers, screenwriters, and cinema studies students. Journal of Film and Video, 71(1), 51-62.

Van Gorp, A. J. (2000). 'Guiding issues of artificial light use in urban landscape architecture'. MPhil thesis. University of Manitoba.

Vanstone, K. M. (1998). 'Media images and effects on mood and eating: A function of dietary restraint?’ Mphil thesis. University of Manitoba. 


\section{ENDNOTES}

${ }^{1}$ The necessity of research into the uses of color in cinematography has been one of the proposed venues of research expressed by CINEJ since its first issue. See Akser (2011) and other relevant research in the field include Misek (2010), Street and Yumibe (2019) and Tomasulo (2019).

$376 \quad$ CINEJ Cinema Journal: Mustafa Mahmoud Yousry Matbouly

Volume 8.2(2020) | ISSN 2158-8724 (online) | DOI 10.5195/cinej.2020.278 | http://cinej.pitt.edu 